\title{
PENGARUH PEMBELAJARAN NILAI-NILAI TOLERANSI UNTUK MENINGKATKAN KETERAMPILAN SOSIAL SISWA SMP
}

\author{
Nuswantari \\ Universitas PGRI Madiun \\ Email: nusinuswantari@gmail.com
}

\begin{abstract}
The purpose of this research is, to know the influence of the tolerance values of teaching influence in improving social skill of junior high school's students. Subject choice is done based on the score of social skill term to 143 students. As the subject of research is student who has < 111, and it is found 28 subject matters, and then from 28 subject concerned, it is divided into two groups, those are experiment's group and controlled one, in random by considering equality if the subject between controlled and experiments groups. The result of data analysis of controlled and experiments groups with the t-test (sample paired t-test) it is known 2,490 with significant 0,027 , it is mean there are differences of score improvement in social skill between controlled and experiences groups. It can be said that the instruction of effective tolerance values will result no difference, therefore it can be said that the effectivity of treatment will be fixed. The conclusion which will be found from this research is the teaching values of effective tolerance can be improving social skill of students
\end{abstract}

\section{Keywords: social skill, tolerance, values}

\section{PENDAHULUAN}

Pada dasarnya manusia adalah makluk sosial yang selalu menjalin relasi, dan senantiasa membutuhkan orang lain. Proses sosialisasi diawali ketika individu berada dalam periode kanak-kanak, dimana mereka akan mencari posisi dalam masyarakat, mengembangkan rasa ikut memiliki, dan memiliki kesediaan untuk memberikan kontribusi kepada masyarakat. Kondisi ini akan mengakibatkan individu melakukan interaksi dengan lingkungannya, baik di lingkungan keluarga, sekolah, maupun lingkungan masyarakat. Supaya proses interaksi sosial dapat berlangsung dengan selaras, diperlukan kemampuan dalam melakukan proses penyesuaian diri. Proses penyesuaian diri ini merupakan salah satu aspek psikologis yang harus memperoleh tempat untuk selalu bisa dikembangkan oleh setiap individu. Proses penyesuaian diri ini menyangkut proses penyesuaian diri dengan individu lain, baik dalam lingkungan sendiri maupun di luar lingkungan individu. Untuk bisa memberikan respon positif terhadap lingkungan, diperlukan keterampilan sosial dalam usaha mencapai penyesuaian sosial yang baik.
Salah satu tugas perkembangan yang harus dikuasai remaja yang berada dalam fase perkembangan masa remaja madya dan remaja akhir adalah memiliki keterampilan sosial (social skill) untuk menyesuaikan diri dengan kehidupan sehari-hari. Keterampilan sosial tersebut meliputi keterampilan intra personal, keterampilan inter personal dan keterampilan yang berhubungan dengan akademis (Cartledge dan Milburn, 1995). Apabila keterampilan sosial dapat dikuasai oleh remaja pada fase tersebut, ia akan mampu menyesuaikan diri dengan lingkungan sosialnya.

Seseorang yang memiliki keterampilan sosial, maka ia akan mampu membuka diri dan menerima orang lain, sehingga mampu menempatkan diri di tengah lingkungan sosialnya. Dalam berinteraksi dengan orang lain, keterampilan ini dapat digunakan untuk mempengaruhi dan memimpin, bermusyawarah dan menyelesaikan perselisihan, serta untuk bekerja sama dan bekerja dalam team.

Kesulitan atau hambatan dalam penyesuaian sosial akan berakibat pada gangguan perilaku pada anak, mulai dari perilaku melawan guru, membohongi guru, sering membolos sekolah, suka mengganggu teman dan memeras uang saku teman, bertengkar dan berkelahi 
dengan teman, sampai melakukan tindakan kriminal lain seperti mencuri, pemakaian narkoba dan minum-minuman keras (Mukhtar dan Hadjam, 2006).

Penelitian Mukhtar dan Hadjam (2006) tentang Efektifitas Art Therapy untuk meningkatkan Keterampilan Sosial pada Anak yang Mengalami Gangguan Perilaku, menunjukkan hasil bahwa sebagian subyek mengalami peningkatan keterampilan sosial, rasa percaya diri dan penghargaan pada diri sendiri.

Crick dan Dodge mengatakan bahwa lemahnya keterampilan sosial, membuat mereka cenderung menunjukkan prasangka permusuhan, saat berhadapan dengan stimulus sosial yang ambigu mereka sering mengartikannya sebagai tindakan permusuhan,sehingga menghadapinya dengan tindakan agresif (Mukhtar dan Hadjam, 2006). Rendahnya keterampilan sosial anak menyebabkan anak kurang mampu menjalin interaksi secara efektif dengan lingkungannya dan memilih tindakan agresif sebagai strategi coping. Mereka cenderung menganggap tindakan agresif merupakan cara yang paling tepat untuk mengatasi permasalahan sosial dan mendapatkan apa yang mereka inginkan (Mukhtar dan Hadjam, 2006).

Shapiro mengatakan bahwa sekitar 50 persen anak-anak yang dirujukkan kebagian pendidikan khusus di sekolah juga diidentifikasi mempunyai keterampilan sosial yang buruk dan cenderung ditolak oleh teman-teman sebaya. Dalam banyak hal masalah sosial pada anak menjadi lebih menonjol dibanding kesulitan dalam pelajaran sekolah. Penolakan teman sebaya pada masa kanak-kanak menjadi salah satu faktor yang ikut menyebabkan buruknya prestasi akademik, timbulnya masalah emosi, dan meningkatnya resiko kenakalan remaja (Shapiro, 1998).

Selama ini upaya sekolah dalam mengantisipasi timbulnya penyimpangan perilaku sosial telah dilakukan melalui proses pembelajaran nilai-nilai toleransi yang terintegrasi kedalam mata pelajaran Ilmu Pengetahuan Sosial (IPS), Pendidikan Kewarganegaraan (PKn) dan Pendidikan Agama. Melalui mata pelajaran IPS, PKn dan Pendidikan Agama ini diharapkan siswa mampu mengembangkan pengetahuan serta nilai-nilai, sikap, moral serta ketrampilan sosialnya. Namun dalam realitanya harapan tersebut belum bisa diwujudkan, mengingat selama ini model pembelajaran IPS, PKn dan Pendidikan Agama lebih menekankan pada aspek kebutuan formal yang lebih berorientasi pada pencapaian nilai akademis tiga bidang studi tersebut, dibanding kebutuhan riil para siswa yang juga membutuhkan bimbingan dalam mengembangkan sikap, mental dan perilakunya, oleh sebab itu proses pembelajaran terkesan sebagai pekerjaan administratif, yaitu sebatas penyampaian isi kurikulum dan belum mengembangkan potensi anak secara optimal. Hal ini seperti yang diungkapkan oleh Amstrong dinyatakan bahwa ada dua wacana pengembangan sekolah dewasa ini, yaitu wacana pengembangan prestasi akademis dan wacana pengembangan manusia. Sedangkan dalam kenyataannya pengembangan prestasi akademislah yang lebih diutamakan (Suyata, 2008).

Pembelajaran keterampilan sosial melalui pendidikan toleransi didasarkan pada suatu pengertian bahwa pembelajaran nilai-nilai toleransi itu berorientasi pada satu tujuan yaitu untuk mencapai kebersamaan, keadilan, kedamaian, kerukunan dan kesejahteraan dalam kehidupan bermasyarakat. Sementara keterampilan sosial adalah kemampuan seseorang dalam berinteraksi sosial, kemampuan seseorang dalam memahami dan memberi penghargaan bagi diri sendiri dan orang lain, kemampuan berkomunikasi dan menjalin persahabatan, kemampuan menyelesaikan konflik secara damai. Dari uraian tersebut, maka tujuan yang akan dicapai dalam penelitian ini adalah ingin mengetahui apakah kecakapan keterampilan sosial siswa SMP dapat ditingkatkan melalui pembelajaran nilai-nilai toleransi di sekolah.

\section{KAJIAN TEORI}

Ketrampilan sosial bukanlah kemampuan yang dibawa individu sejak lahir, tetapi diperoleh melalui proses belajar, baik belajar dari orang tua sebagai figur yang paling dekat dengan anak, maupun belajar dari teman sebaya dan lingkungan masyarakat. Menurut Michelson (Syamril, J. R dan Irwan N. K., 2008) dinyatakan bahwa keterampilan sosial meliputi keterampilanketerampilan memberikan pujian, mengeluh 
karena tidak setuju terhadap sesuatu hal, menolak permintaan orang lain, kemampuan bertukar pengalaman, menuntut hak pribadi, memberikan saran kepada orang lain, pemecahan konflik atau masalah, serta berhubungan dengan orang lain yang lebih tua atau yang lebih tinggi statusnya. Sementara Goleman mengatakan bahwa keterampilan sosial adalah kemampuan anak untuk mengendalikan emosinya dengan baik pada saat berhubungan dengan orang lain, memiliki kemampuan untuk membaca situasi dan mampu berinteraksi dengan lancar, serta menjalin persahabatan dengan sehat (Goleman, 1999).

Menurut hasil studi Davis dan Forsythe dinyatakan bahwa dalam kehidupan remaja terdapat delapan aspek yang menuntut keterampilan sosial (social skills), yaitu (a) keluarga (b) lingkungan (c) kepribadian (d) rekreasi (e) pergaulan dengan lawan jenis (f) pendidikan/sekolah (g) persahabatan dan solidaritas kelompok dan (h) lapangan kerja (Thalib, 2010). Dalam pengembangan aspek psikososial remaja, aspek-aspek yang menuntut keterampilan sosial remaja harus dapat dikembangkan sedemikian rupa, sehingga dapat memberikan kondisi yang kondusif.

Menurut Prayitno dikatakan bahwa metode-metode yang dapat digunakan guru untuk meningkatkan keterampilan sosial siswa mencakup kegiatan: (a) diskusi kelompok (diskusi kelompok besar/kecil) (b) diskusi panel (c) simposium (d) ceramah (e) seminar (f) role playing (permainan peran) atau sosiodrama (g) brainstorming (h) pemecahan masalah (i) inquiry dan (j) tutorial. Sementara itu cara-cara berketerampilan sosial dapat dikembangkan kepada siswa dengan cara : (a) membuat rencana dengan produkif dalam diskusi kelompok (b) menjawab secara sopan pertanyaan orang lain (c) memimpin diskusi kelompok (d) betindak secara betanggung jawab dan (e) menolong orang lain (Thalib, 2010). Seorang siswa dikatakan mampu berketerampilan sosial pada saat si siswa dapat berkomunikasi dengan baik sesuai aturan (tata cara) dengan sesamanya di dalam sebuah kelompok

Toleransi merupakan salah satu bentuk akomodasi tanpa adanya persetujuan formal. Kadang-kadang toleransi muncul secara tidak sadar dan tanpa direncanakan, hal ini disebabkan oleh watak seseorang atau kelompok manusia untuk sedapat mungkin menghindarkan diri dari perselisihan (Sukanto,2010).

Selanjutnya Zagorin mengatakan bahwa toleransi adalah istilah dalam konteks sosial, budaya dan agama, yang berarti sikap dan perbuatan yang melarang adanya diskriminasi terhadap kelompok-kelompok yang berbeda atau tidak dapat diterima oleh mayoritas dalam suatu masyarakat (Subkhan, 2007). United Nations Educational, Scientific and Cultural Organization (UNESCO) menyatakan bahwa "Toleransi" adalah sikap saling menghormati, saling menerima, saling menghargai di tengah keragaman budaya, kebebasan berekspresi dan karakter manusia. Untuk itu toleransi harus didukung oleh cakrawala pengetahuan yang luas, bersikap terbuka, dialog, kebebasan berpikir dan beragama. Singkatnya toleransi setara dengan bersikap positif dan menghargai orang lain dalam rangka menggunakan kebebasan asasi sebagai manusia.

Bentuk pendidikan toleransi yang menyajikan pengalaman hisdup bersama dan menghargai berbagai perbedaan antara lain dipopulerkan oleh Vogt (1997). Pendidikan toleransi ini sering juga disebut sebagai pendidikan multikultural atau pendidikan perdamaian. Menurut Vogt pendidikan toleransi dapat dilakukan dengan dua model, yaitu : model pendidikan toleransi langsung (direct), dan model pendidikan toleransi tidak langsung (indirect). Model yang pertama; menekankan pada interaksi sosial secara langsung antar kelompok siswa (intergroup contact) yang beragam latar belakangnya, sehingga model ini mengharuskan keragaman latar belakang siswa dalam proses pembelajaran. Sedangkan model yang kedua; menekankan pada pengembangan kepribadian (personality development) para siswa yang terbuka terhadap perbedaan. Model ini tidak mengharuskan keragaman latar belakang siswa dalam proses pembelajaran.

Menurut Vogt (1997), pendidikan toleransi di beberapa negara di atas memiliki pengaruh yang cukup signifikan terhadap penurunan kuantitas terjadinya sikap stereotip dan prasangka, dan perilaku diskriminatif. Di sisi lain, model pendidikan toleransi pada tingkat tertentu dapat berdampak pada sikap penerimaan para 
siswa terhadap siswa lain yang berbeda etnik, warna kulit dan agama

Menurut Walzer (1997), mengatakan bahwa toleransi memiliki lima level, yaitu dari level bawah yang sangat tradisional hingga yang sangat modern. Hal tersebut dijelaskan sebagai berikut: Pada tahap awal; toleransi bisa dianalogikan ibarat dua kelompok mafia yang saling bertengkar dan terus berperang. Ketika mereka kelelahan karena terus menerus dalam kondisi yang tidak aman dan damai disebabkan oleh peperangan yang mereka lakukan, maka mereka akhirnya memutuskan untuk berhenti berperang. Namun, disini tidak terjadi suatu dialog dan kesepakatan diantara dua belah pihak yang bertikai, mereka tetap eksis satu sama lain. Hal ini tetap dapat disebut sebagai suatu sikap yang Toleran, dalam bentuknya yang sangat tradisional. Mereka (atau kita) memandang Other tetap eksis, tapi mereka (kita) tidak mau peduli dan juga tidak mau mengakui (sebenarnya) dengan segala sikap dan ekspresi others/stranger tersebut. Toleransi dalam bentuk seperti ini sebenarnya sangat lemah dan sewaktu-waktu dapat hilang sehingga memicu kembali terjadinya konflik.

Toleransi pada level kedua; dapat dianalogikan sebagai sikap "cuek" kita terhadap orang lain (other/stranger) ketika bertemu di suatu tempat, yang mana kita mengakui adanya orang lain tersebut tapi kita tidak memiliki hasrat untuk mau mengenalnya, atau berkomunikasi (sekedar menyapa). Kita hanya bersikap "cuek" atau tak acuh, dan ini sebenarnya pula sudah termasuk dalam sikap yang toleran dalam bentuknya yang sangat tradisional pula, yang tak jauh beda dengan toleransi pada level sebelumnya.

Pada tahap atau level yang ketiga; Toleransi berwujud dalam bentuk 'respect' kita terhadap yang lain/other. Respect disini merupakan suatu sikap atau perilaku yang mendorong kita untuk mengenal dan menghargai yang lain. Dalam hal ini, kita dituntut untuk bisa menekan rasa emosi, ketidaksenangan, atau ketidaknyamanan kita terhadap orang lain/other tersebut, yang timbul dari perbedaan antara orang lain dengan diri atau kelompok kita. Sikap respect disini bukanlah berarti kita menerima orang lain hanya karena kita "senang" dengan orang lain itu dalam bersikap dan berperilaku atau cocok seperti yang kita inginkan (atau sesuai dengan persepsi kita), tetapi respect lebih merupakan sikap penerimaan kita terhadap kekurangan dan perbedaan yang dimiliki oleh orang lain/other tersebut.

Toleransi pada tahap berikutnya juga lebih maju, atau modern, yaitu toleransi yang altruistik. Toleransi dalam level ini merupakan suatu sikap penerimaan kita terhadap other atau stranger bukan karena perbedaan yang dimiliki oleh other atau stranger tersebut, tetapi kita lebih melihat eksistensi orang lain (other) sebagai sebuah refleksi nilai-nilai luhur dan ideal dari negara, agama, kebudayaan, dan ideologi. Sehingga dari sikap ini akan lahir sebuah bentuk sikap yang saling mendukung, kerjasama, saling menghormati, dan bertenggang rasa, dalam kehidupan berbangsa dan bernegara yang sangat majemuk dan plural.

Selanjutnya, toleransi pada level yang terakhir ini merupakan toleransi yang lebih bersifat "multikulturalisme", yaitu suatu sikap toleran yang bukan hanya didasari oleh sikap pengakuan kita, sikap penghormatan, dan sikap penerimaan terhadap segala perbedaan yang ada pada 'orang lain', tetapi juga adanya suatu sikap dari kita untuk mau berbaur dan menyatu serta belajar dari hal-hal baru yang ada pada 'orang lain, other, stranger', sehingga dapat menciptakan suatu 'self development' pada diri kita/kelompok kita khususnya, dan dalam komunitas yang lebih luas pada umumnya. Selanjutnya akan mampu tercipta suatu kehidupan yang harmonis, tenteram dan damai. Dalam suatu kehidupan masyarakat yang plural (seperti Indonesia), sikap toleransi sangat dibutuhkan. Sikap toleransi ini juga harus bisa didukung dengan suatu dialog yang membawa pada kesepakatan pada dua atau lebih kelompok/komunitas yang berbeda. Dalam suatu masyarakat yang tingkat kesepakatan (dialog/kesepakatan) tinggi, maka toleransi akan semakin tinggi. Sedangkan jika tingkat kesepakatan rendah maka toleransi akan lebih rendah juga.

Menurut Gordon (Goleman, 1999), ada empat langkah dalam mengajarkan toleransi yaitu Pertama; pengenalan keragaman, dimulai dengan memberi pengertian bahwa ada beragam suku, agama, budaya. Meskipun orang lain memiliki agama atau suku yang berbeda, manusia sebenarnya sama dan tidak boleh dibeda-bedakan. 
Memperkenalkan keragaman sedini mungkin dapat memupuk jiwa toleransi anak agar lebih memandang perbedaan yang ada secara lebih bijak. Kedua; perbedaan bukan untuk menimbulkan kebencian. Anak diajarkan bahwa perbedaan yang ada, tidak boleh disikapi dengan kebencian, karena kebencian akan membuat sedih dan menyakiti hati orang lain. Anak diajak untuk berandai-andai, misalnya jika anak dibenci karena perbedaan, tentu akan merasa sedih. Dengan demikian anak lebih merasa berempati dan bertoleransi dengan apa yang dirasakan orang lain. Ketiga; peneladanan dan pengajaran tidak terbatas lewat kata-kata, tetapi juga contoh nyata. Keempat; bertoleransi untuk kedamaian, apabila tidak ada sikap toleransi, banyak orang yang akan bermusuhan dan saling membenci. Untuk menumbuhkan dan mengembangkan sikap toleransi pada anak ini, Nuswantari mengatakan dapat dilakukan oleh orang tua dalam keluarga, dan dapat dilakukan oleh guru disekolah (Nuswantari, 2018).

Pembelajaran toleransi pada anak-anak sebaiknya dimulai dari sikap orangtua yang menghargai perbedaan-perbedaan itu dengan baik, yaitu dengan menjadi diri mereka sendiri, tanpa sikap yang dibuat-buat. Lingkungan rumah dan sekolah memegang peranan penting dalam mengembangkan toleransi beragama. Jika lingkungan rumah atau sekolah yang ditemui anak bersifat heterogen, anak dapat memahami perbedaan agama dan kebiasaan yang dilakukan masing-masing agama, karena anak-anak biasanya belajar dari apa yang dilihat dan didengar dari orang tua dan orang-orang di sekitarnya. Perilaku orang tua yang menghargai sesama akan dicontoh anaknya, dan memberi pengaruh yang besar terhadap anak, sehingga anak akan lebih menghargai tentang perbedaan.

Conger (dalam Indreswari Henny dkk, 2010) menyebutkan bahwa individu yang memiliki keterampilan sosial tinggi, cenderung diterima oleh lingkungannya, individu akan memiliki kepuasan dalam hidupnya, memiliki kepercayaan diri yang tinggi, memiliki harga diri, punya rasa humor, selalu optimis terhadap masa depannya, memiliki antusiasme, inisiatif dan semangat hidup tinggi, mereka bebas untuk mengekspresikan pikiran dan perasaannya. Sedangkan individu yang mengalami kesulitan dalam penyesuaian sosialnya, rasa percaya dirinya rendah, kurang bisa mempercayai orang lain, selalu diliputi oleh perasaan khawatir, tidak aman, ragu-ragu, konsep dirinya negatif, selalu merasa tidak puas terhadap kehidupannya, sulit untuk mengekspresikan pikiran dan perasaannya secara bebas, selalu merasa tertekan, dan merasa pesimis terhadap kehidupannya. Ketrampilan sosial merupakan salah satu faktor yang menentukan kemampuan penyesuaian diri. Kegagalan remaja dalam menguasai keterampilan-keterampilan sosial akan menyebabkan remaja sulit menyesuaikan diri dengan lingkungan sekitarnya.

Toleransi merupakan salah satu bentuk akomodasi tanpa adanya persetujuan formal. Kadang-kadang toleransi muncul secara tidak sadar dan tanpa direncanakan, hal ini disebabkan oleh watak seseorang atau kelompok manusia, untuk sedapat mungkin menghindarkan diri dari suatu perselisihan (Soekanto, 2010). United Nations Educational, Scientific and Cultural Organization (UNESCO) menyatakan bahwa "Toleransi" adalah sikap "saling menghormati, saling menerima, saling menghargai di tengah keragaman budaya, kebebasan berekspresi dan karakter manusia. Untuk itu toleransi harus didukung oleh cakrawala pengetahuan yang luas, bersikap terbuka, dialog, kebebasan berpikir dan beragama. Singkatnya toleransi setara dengan bersikap positif dan menghargai orang lain dalam rangka menggunakan kebebasan asasi sebagai manusia.

Pelaksanaan pendidikan toleransi didasarkan pada suatu pengertian bahwa pembelajaran nilai-nilai toleransi berorientasi pada tujuan untuk mencapai kehidupan bermasyarakat. Hal ini sejalan dengan apa yang dikatakan oleh Nuswantari, bahwa dengan sikap toleransi seseorang didalam menghadapi keadaan yang tidak sesuai dengan harapannya, tidak akan secara spontan mengatakan perasaan negatifnya, melainkan dia akan berusaha menerima hal tersebut sebagai suatu yang patut dihargai. Sementara keterampilan sosial adalah kemampuan seseorang dalam berinteraksi sosial, kemampuan seseorang dalam memahami dan memberi penghargaan bagi diri sendiri dan orang lain, kemampuan berkomunikasi dan menjalin persahabatan, kemampuan menyelesaikan konflik 
secara damai (Nuswantari, 2018). Dari uraian tersebut dapat dikatakan bahwa seseorang yang mempunyai pemahaman serta penguasaan tentang nilai-nilai toleransi dapat mendukung tercapainya keterampilan osialnya.

Bertitik tolak dari pengertian keterampilan sosial dan toleransi, maka keterampilan sosial dan toleransi mempunyai sifat berbanding lurus, artinya seseorang yang mempunyai sikap toleransi, maka seseorang tersebut juga memiliki keterampilan sosial yang tinggi, sebaliknya seseorang yang sikap toleransinya rendah, maka juga rendah keterampilan sosialnya

\section{METODE PENELITIAN}

Penelitian ini menggunakan pendekatan kuantitatif eksperimental dengan rancangan pretest dan post-test control designs. Menggunakan variabel tergantung yaitu keterampilan sosial siswa dan variabel bebas yaitu pembelajaran nilainilai toleransi.

Tempat penelitian dilakukan di SMP Negeri 4 Madiun, sebagai subyek penelitian adalah siswa kelas VIII terdapat 4 kelas, dengan jumlah siswa sebanyak 143 siswa. Selanjutnya 143 siswa akan mengisi angket keterampilan sosial yang terdiri dari 37 item. Dengan variasi skor adalah 1, 2, 3, 4 untuk setiap item, maka akan diperoleh skor terendah 37 dan skor tertinggi 148.

Hasil pengukuran terhadap 143 siswa diperoleh skor keterampilan sosial terendah 88 dan tertinggi 144. Berdasarkan hasil tersebut maka siswa yang dipilih untuk subyek penelitian adalah siswa yang memiliki skor kurang dari 111, dengan kriteria tersebut diperoleh 28 subyek. Selanjutnya subyek (28 siswa) dibagi menjadi dua kelompok, yaitu kelompok kontrol dan kelompok eksperimen dengan memperhatikan kesetaraan individu pada masing-masing kelompok.

Metode pengumpulan data yang digunakan dalam penelitian ini adalah dengan menggunakan skala keterampilan sosial dan observasi. Skala keterampilan sosial disusun berdasarkan aspekaspek interpersonal, intrapersonal dan kemampuan yang berhubungan dengan akademis. Sedangkan observasi menggunakan pedoman observasi dari Prihartanti dkk (2007).
Pengumpulan data dalam penelitian ini menggunakan skala ketrampilan sosial dengan model skala Likert, yang terdiri dari tiga puluh tujuh item. Skala ketrampilan sosial terdiri dari pernyataan-pernyataan dengan empat pilihan jawaban yaitu sangat setuju (SS), setuju (S), tidak setuju (TS), sangat tidak setuju (STS) (Azwar, 2004). Keempat pilihan jawaban tersebut diberi skor $\mathrm{SS}=4 ; \mathrm{S}=3$; $\mathrm{TS}=2$; $\mathrm{STS}=1$ untuk pernyataan favorable dan untuk pernyataan unfavorable diberi skor $\mathrm{SS}=1 ; \mathrm{S}=2 ; \mathrm{TS}=3 ; \mathrm{STS}=4$.

\section{Tabel 1. Blue Print Ketrampilan Sosial}

\begin{tabular}{|c|c|c|c|c|}
\hline No & Aspek & $\begin{array}{c}\text { Favour } \\
\text { abel }\end{array}$ & $\begin{array}{c}\text { Unfavour } \\
\text { abel }\end{array}$ & Jumlah \\
\hline 1. & Interpersonal & $\begin{array}{l}1,3,4, \\
6,7,8, \\
10\end{array}$ & $2,5,9,11$ & 11 \\
\hline 2. & Intrapersonal & $\begin{array}{l}12,14, \\
16,18, \\
20,22\end{array}$ & $\begin{array}{l}13,15,17, \\
19,21\end{array}$ & 11 \\
\hline 3. & $\begin{array}{l}\text { Kesuksesan } \\
\text { Akademis }\end{array}$ & $\begin{array}{l}23,24, \\
25,26, \\
28,29, \\
31,32, \\
33,35, \\
36,37\end{array}$ & $27,30,34$ & 15 \\
\hline & & 25 & 12 & 37 \\
\hline
\end{tabular}

Alternatif jawaban bagi item Favourabel dan nilainya:

$$
\begin{array}{rlrl}
\text { SS } & \begin{array}{l}
\text { Sangat sesuai, } \\
\text { dinilai } 4
\end{array} \\
\text { TS } & \text { S Tidak sesuai } & \text { STS } & \text { Sesuai, dinilai } 3 \\
& =\text { Sangat tidak } \\
\text { dinilai } 2 & & & \text { sesuai, dinilai } 1
\end{array}
$$

Alternatif jawaban bagi item Unfavourabel dan nilainya:

$$
\begin{aligned}
& \text { SS = Sangat sesuai } \mathrm{S}=\text { Sesuai, dinilai } 2 \\
& \text { dinilai } \\
& \text { TS = Tidak sesuai } \text { STS }=\text { Sangat tidak } \\
& \text { dinilai } 3 \quad \text { sesuai, dinilai } 1
\end{aligned}
$$

Observasi dilakukan selama proses perlakuan, bertujuan untuk mengetahui sikap, respon dan aktifitas siswa selama proses perlakuan. Pedoman observasi dalam pembelajaran nilai-nilai toleransi menurut Prihartanti (Prihartanti, N. Abdulah, A. Eny, P., 2007) 
Tabel 2. Pedoman Observasi saat Perlakuan

\begin{tabular}{|l|l|l|}
\hline \multicolumn{1}{|c|}{ Daftar Performance } & Ya/Tidak & Ket. \\
\hline $\begin{array}{l}\text { Memperhatikan ketika } \\
\text { pengajar menunjukkan bahan } \\
\text { pengajaran }\end{array}$ & & \\
\hline $\begin{array}{l}\text { Memperhatikan ketika } \\
\text { pengajar memberi penjelasan }\end{array}$ & & \\
\hline Menjawab pertanyaan & & \\
\hline Ikut melakukan kegiatan & & \\
\hline
\end{tabular}

Penelitian ini menggunakan pre-test dan post-test kontrol designs, dengan rancangan sebagai berikut:

Tabel 3. Rancangan Eksperimen

\begin{tabular}{|c|c|c|c|c|}
\hline Kelompok & Pretest & Treatman & Postest & $\begin{array}{c}\text { Follow- } \\
\text { up }\end{array}$ \\
\hline $\begin{array}{c}\text { KE } \\
\text { (eksperime) }\end{array}$ & $\mathrm{Y} 1$ & $\mathrm{X}$ & $\mathrm{Y} 2$ & $\mathrm{Y} 3$ \\
\hline $\begin{array}{c}\text { KK } \\
\text { (kontrol) }\end{array}$ & $\mathrm{Y} 1$ & - & $\mathrm{Y} 2$ & $\mathrm{Y} 3$ \\
\hline
\end{tabular}

Keterangan:

Y1 : hasil pengukuran keterampilan sosial sebelum perlakuan

$\mathrm{X}$ : perlakuan pembelajaran nilai-nilai toleransi

Y2 : hasil pengukuran keterampilan sosial setelah pengukuran

Y3 : hasil pengukuran setelah post-test

Modul yang digunakan dalam penelitian ini adalah modul pembelajaran toleransi yang disusun oleh Prihartanti dkk (2007). Pertimbangan penggunaan modul ini adalah bahwa secara konseptual modul sudah divalidasi oleh pakar, yang terdiri dari seorang pakar dengan kompetensi kajian bidang multikultural, seorang pakar bidang pendidikan dan seorang pakar praktisi psikologi anak. Hasil validasi menunjukkan bahwa modul Pembelajaran Toleransi memiliki ketepatan sebesar 73,93 \% untuk mengajarkan nilai-nilai toleransi (Prihartanti, 2007).

Tabel 4. Kompetensi dan Metode tiap Aktivitas Pembelajaran Toleransi

\begin{tabular}{|c|c|c|}
\hline $\begin{array}{c}\text { Kegiatan dan } \\
\text { Materi Aktivitasnya }\end{array}$ & Kompetensi & Metode \\
\hline $\begin{array}{l}\text { Peningkatan } \\
\text { kemampuan } \\
\text { menghargai } \\
\text { sendiri: }\end{array}$ & $\begin{array}{l}\text { Siswa mampu } \\
\text { menghargai } \\
\text { diri sendiri }\end{array}$ & $\begin{array}{l}\text { Pengamatan } \\
\text { terstruktur }\end{array}$ \\
\hline
\end{tabular}

\begin{tabular}{|c|c|c|}
\hline $\begin{array}{l}\text { 1. Bintang dalam } \\
\text { Apel } \\
\text { 2. Berikan Popcorn- } \\
\text { nya }\end{array}$ & & \\
\hline $\begin{array}{l}\text { Peningkatan } \\
\text { keterampilan } \\
\text { Dalam memberi dan } \\
\text { menerima } \\
\text { penghargaan dalam } \\
\text { Pergaulan sosial: } \\
\text { 3. Lima kata } \\
\text { penjaga } \\
\text { hubungan. } \\
\text { 4. Penghargaan } \\
\text { 5. Kelihatan dan } \\
\text { tidak kelihatan } \\
\end{array}$ & $\begin{array}{l}\text { Siswa } \\
\text { memiliki } \\
\text { keterampilan } \\
\text { sosial dalam } \\
\text { memberi dan } \\
\text { menerima } \\
\text { penghargaan } \\
\text { dalam } \\
\text { pergaulan } \\
\text { dengan orang } \\
\text { lain }\end{array}$ & $\begin{array}{l}\text { - Bermain } \\
\text { peran } \\
\text { - PermainanB } \\
\text { ercerita } \\
\text { dengan } \\
\text { penghargaa } \\
\text { n }\end{array}$ \\
\hline $\begin{array}{l}\text { Pengenalan tindakan } \\
\text { toleran dan tidak } \\
\text { toleran, serta } \\
\text { penghargaan } \\
\text { terhadap keragaman: } \\
\text { 6. Nilai sebuah jiwa } \\
\text { 7. Si Pendek dan Si } \\
\quad \text { Jangkung }\end{array}$ & $\begin{array}{l}\text { Siswa } \\
\text { mengenal } \\
\text { tindakan } \\
\text { toleran dan } \\
\text { tidak toleran } \\
\text { serta mampu } \\
\text { saling } \\
\text { menghargai } \\
\text { dalam } \\
\text { keragaman }\end{array}$ & $\begin{array}{l}\text { - Pengamatan } \\
\text { berstruktur } \\
\text { - Bercerita }\end{array}$ \\
\hline $\begin{array}{l}\text { Peningkatan } \\
\text { kemampuan } \\
\text { penyelesaian konflik } \\
\text { secara damai : } \\
\text { 8. Di balik } \\
\text { kemarahan } \\
\text { 9. Tanganku } \\
\text { untuk... } \\
\text { 10. Strategi } \\
\text { menyelesaikan } \\
\text { konflik } \\
\end{array}$ & $\begin{array}{l}\text { Siswa } \\
\text { memiliki } \\
\text { pengetahuan, } \\
\text { pengalaman } \\
\text { damai bagi diri } \\
\text { sendiri dan } \\
\text { orang lain } \\
\text { serta mampu } \\
\text { menyelesaikan } \\
\text { konflik secara } \\
\text { damai } \\
\end{array}$ & $\begin{array}{l}\text { - Eksplorasi } \\
\text { pengalaman } \\
\text { pribadi } \\
\text { - Permainan }\end{array}$ \\
\hline
\end{tabular}

Sumber: Prihartanti (2007)

Pengujian hipotesis untuk mengetahui dampak intervensi, perbedaan antara kelompok kontrol dan kelompok eksperimen adalah dengan menggunakan paired sampel t-test. Demikian juga untuk mengetahui apakah dampak yang ada bersifat permanen atau tidak, yaitu dengan mengetahui perbedaan pengukuran follow-up dengan skor post-test pada kelompok eksperimen.

\section{HASIL DAN PEMBAHASAN}

Pengukuran data dilakukan tiga kali, pengukuran pertama; dilakukan sebelum pemberian perlakuan (pre-test). Pengukuran kedua; dilakukan sepuluh hari sesudah perlakuan (post-test). Pengukuran ketiga; dilakukan sepuluh hari sesudah pos-test (follow-up). Semua pengukuran tersebut diberlakukan kepada kelompok kontrol maupun kelompok eksperimen. 
Hasil pengukuran selisih pre test dengan post test kelompok kontrol akan diperbandingkan dengan hasil pengukuran selisih pre test dengan post test kelompok eksperimen, untuk mengetahui efektifitas perlakuan. Adapun hasil pos-test eksperimen akan diperbandingkan dengan hasil follow-up eksperimen, untuk mengetahui apakah pengaruh perlakuan tersebut bersifat sementara atau permanen. Hasil pengukuran selengkapnya adalah seperti pada tabel dibawah ini.

Tabel 5. Data Hasil Pengukuran Kelompok Eksperimen

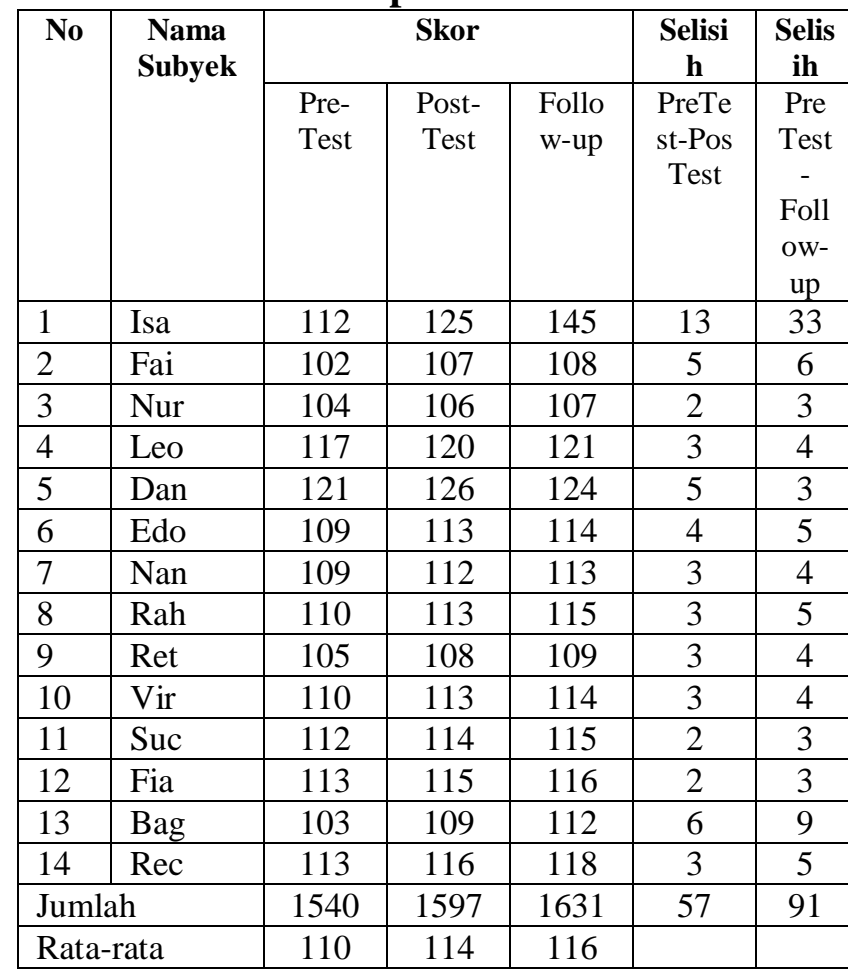

Berdasarkan tabel 5 diatas menunjukkan bahwa rerata skor keterampilan sosial pada kelompok eksperimen sebelum perlakuan (pretest) adalah 110 , rerata skor keterampilan sosial setelah perlakuan (post-test) adalah 114 dan rerata skor keterampilan sosial hasil pengukuran tindak lanjut (follow-up) adalah 116, hal ini menunjukkan bahwa terjadi peningkatan rerata skor keterampilan sosial setelah diberi perlakuan pembelajaran toleransi. Artinya pembelajaran nilai-nilai roleransi berpengaruh terhadap keterampilan sosial siswa.

Tabel 6. Hasil Analysis uji t-paired simpel test

\begin{tabular}{|l|c|c|c|}
\hline \multicolumn{1}{|c|}{ Kelompok } & T & Df & Sign \\
\hline $\begin{array}{l}\text { Pre-Post } \\
\text { Eksperimen }\end{array}$ & 2,490 & 13 & 0,027 \\
\hline
\end{tabular}

\begin{tabular}{|l|l|l|l|}
\hline vs Pre-Post & & & \\
Kontrol & & & \\
\hline
\end{tabular}

Berdasarkan Uji-t diketahui, bahwa $\mathrm{t}=$ 2,490 dengan signifikansi 0,027 berarti ada perbedaan peningkatan skor ketrampilan sosial antara kelompok kontrol dengan kelompok eksperimen. Pembelajaran nilai-nilai toleransi berpengaruh terhadap ketrampilan sosial siswa.

\section{Tabel 7. Hasil analysis post-test vs follow-up kelompok eksperimen}

\begin{tabular}{|l|c|c|c|}
\hline Kelompok & T & Df & Sign \\
\hline $\begin{array}{l}\text { Post test vs } \\
\text { follow-up } \\
\text { eksperimen }\end{array}$ & $-1,758$ & 13 & 0,102 \\
\hline
\end{tabular}

Selanjutnya berdasar hasil analisis Uji-t antara skor post-test dan follow-up pada kelompok eksperimen ditemukan bahwa $\mathrm{t}=$ 1,758 dengan signifikansi $=0,102$ berarti tidak ada perbedaan, dengan demikian dapat dikatakan bahwa efek perlakuan bersifat menetap.

Tabel 8. Hasil Pengukuran dan Klasifikasi Keterampilan Sosial

\begin{tabular}{|c|c|c|c|c|c|c|c|}
\hline $\begin{array}{c}\text { Subye } \\
\mathbf{k}\end{array}$ & $\begin{array}{l}\text { pre- } \\
\text { test }\end{array}$ & $\begin{array}{l}\text { Klasi } \\
\text { fikasi }\end{array}$ & $\begin{array}{c}\text { post- } \\
\text { test }\end{array}$ & $\begin{array}{l}\text { Klasi } \\
\text { fikasi }\end{array}$ & $\begin{array}{c}\text { selisih } \\
\text { pre- post } \\
\text { test }\end{array}$ & $\begin{array}{c}\text { Follow- } \\
\text { up }\end{array}$ & $\begin{array}{l}\text { klasifik } \\
\text { asi }\end{array}$ \\
\hline 1 & 112 & tinggi & 125 & $\begin{array}{l}\text { Tingg } \\
\mathrm{i}\end{array}$ & 13 & 145 & $\begin{array}{l}\text { Sangat } \\
\text { tinggi }\end{array}$ \\
\hline 2 & 102 & $\begin{array}{l}\text { sedan } \\
\mathrm{g}\end{array}$ & 107 & $\begin{array}{l}\text { Sedan } \\
\mathrm{g}\end{array}$ & 5 & 108 & Sedang \\
\hline 3 & 104 & $\begin{array}{l}\text { sedan } \\
\mathrm{g}\end{array}$ & 106 & $\begin{array}{l}\text { Sedan } \\
\mathrm{g}\end{array}$ & 2 & 107 & Sedang \\
\hline 4 & 117 & tinggi & 120 & Tingg & 3 & 121 & Tinggi \\
\hline 5 & 121 & tinggi & 126 & $\begin{array}{l}\text { Tingg } \\
\mathrm{i}\end{array}$ & 5 & 124 & Tinggi \\
\hline 6 & 109 & $\begin{array}{l}\text { sedan } \\
\mathrm{g}\end{array}$ & 113 & $\begin{array}{l}\text { Tingg } \\
\mathrm{i}\end{array}$ & 4 & 114 & Tinggi \\
\hline 7 & 109 & $\begin{array}{l}\text { sedan } \\
\mathrm{g}\end{array}$ & 112 & $\begin{array}{l}\text { Tingg } \\
\mathrm{i}\end{array}$ & 3 & 113 & Tinggi \\
\hline 8 & 110 & $\begin{array}{l}\text { sedan } \\
\mathrm{g}\end{array}$ & 113 & $\begin{array}{l}\text { Tingg } \\
\mathrm{i}\end{array}$ & 3 & 115 & Tinggi \\
\hline 9 & 105 & $\begin{array}{l}\text { sedan } \\
\mathrm{g}\end{array}$ & 108 & $\begin{array}{l}\text { Sedan } \\
\mathrm{g}\end{array}$ & 3 & 109 & Sedang \\
\hline 10 & 110 & $\begin{array}{l}\text { sedan } \\
\mathrm{g}\end{array}$ & 113 & $\begin{array}{l}\text { Tingg } \\
\mathrm{i}\end{array}$ & 3 & 114 & Tinggi \\
\hline 11 & 112 & tinggi & 114 & $\begin{array}{l}\text { Tingg } \\
\mathrm{i}\end{array}$ & 2 & 115 & Tinggi \\
\hline 12 & 113 & tinggi & 115 & $\begin{array}{l}\text { Tingg } \\
\mathrm{i}\end{array}$ & 2 & 116 & Tinggi \\
\hline 13 & 103 & $\begin{array}{l}\text { sedan } \\
\mathrm{g}\end{array}$ & 109 & $\begin{array}{l}\text { Sedan } \\
\mathrm{g}\end{array}$ & 6 & 112 & Tinggi \\
\hline 14 & 113 & tinggi & 116 & $\begin{array}{l}\text { Tingg } \\
\mathrm{i}\end{array}$ & 3 & 118 & Tinggi \\
\hline $\begin{array}{l}\text { Jumla } \\
\mathrm{h}\end{array}$ & 1551 & & 1573 & & & 1572 & \\
\hline Rerata & $\begin{array}{l}110,7 \\
8\end{array}$ & & 112,35 & & & 112,28 & \\
\hline
\end{tabular}

Berdasarkan data tabel 8, diketahui bahwa terjadi kenaikan skor keterampilan sosial sesudah 
perlakuan (post-test), baik secara skor rata-rata maupun skor setiap individu. Jika dilihat dari kategori klasifikasi keterampilan sosial antara pre-test dan pos-test, hasil yang diperoleh adalah: klasifikasi sedang menjadi sedang terdapat empat subyek (28,57\%), klasifikasi sedang menjadi tinggi terdapat 4 subyek $(28,57 \%)$, dan klasifikasi tinggi menjadi tinggi terdapat enam subyek $(42,86 \%)$.

Tabel 9. Rangkuman Klasifikasi
Keterampilan Sosial
\begin{tabular}{|c|c|c|c|}
\hline $\begin{array}{c}\text { Klasifikasi } \\
\text { keterampilan } \\
\text { sosial }\end{array}$ & $\begin{array}{c}\text { pre- } \\
\text { test }\end{array}$ & $\begin{array}{c}\text { Post- } \\
\text { test }\end{array}$ & $\begin{array}{c}\text { Follow- } \\
\text { up }\end{array}$ \\
\hline Tinggi & - & - & 1 \\
\hline Agak Tinggi & 6 & 10 & 10 \\
\hline Sedang & 8 & 4 & 3 \\
\hline Agak sedang & - & - & - \\
\hline Agak Rendah & - & - & - \\
\hline Rendah & - & - & - \\
\hline
\end{tabular}

Berdasarkan klasifikasi keterampilan sosial seperti pada tabel 9 diatas, bahwa sebelum perlakuan terdapat enam subyek $(42,86 \%)$ yang memiliki keterampilan sosial agak tinggi, dan delapan subyek $(57,14 \%)$ memiliki keterampilan sosial sedang. Setelah perlakuan ditemukan sepuluh subyek $(71,43 \%)$ memiliki keterampilan sosial agak tinggi, dan empat subyek $(28,57 \%)$ memiliki keterampilan sosial sedang. Hasil pengukuran tindak lanjut diperoleh hasil satu subyek $(7,14 \%)$ memiliki keterampitan sosial tinggi, sepuluh subyek $(71,43 \%)$ memiliki keterampilan sosial agak tinggi dan tiga subyek $(21,43 \%)$ memiliki keterampilan sedang.

\section{Tabel 10. Hasil Pengukuran Selisih Skor Kelompok Kontrol dan Kelompok} Eksperimen

\begin{tabular}{|c|c|c|}
\hline No & Kontrol & Eksperimen \\
\hline 1 & 1.00 & 13.00 \\
\hline 2 & 7.00 & 5.00 \\
\hline 3 & 1.00 & 2.00 \\
\hline 4 & 0.00 & 3.00 \\
\hline 5 & 7.00 & 5.00 \\
\hline 6 & 1.00 & 4.00 \\
\hline 7 & 0.00 & 3.00 \\
\hline 8 & 1.00 & 3.00 \\
\hline 9 & 2.00 & 3.00 \\
\hline 10 & -4.00 & 3.00 \\
\hline 11 & 2.00 & 2.00 \\
\hline 12 & 2.00 & 2.00 \\
\hline
\end{tabular}

\begin{tabular}{|c|c|c|}
\hline 13 & 0.00 & 6.00 \\
\hline 14 & 2.00 & 3.00 \\
\hline Jumlah & 33 & 57 \\
\hline Rata-rata & 2,35 & 4,07 \\
\hline
\end{tabular}

Berdasarkan tabel 10, tentang Hasil pengukuran selisih skor kelompok kontrol dan kelompok eksperimen, terdapat kenaikan rata-rata selisih skor antara kelompok kontrol dan kelompok eksperimen.

Hasil observasi menunjukkan sikap subyek selama berlangsungnya proses pembelajaran toleransi adalah: Secara rata-rata 88,57 \% subyek memberikan perhatian terhadap berlangsungnya pembelajaran, partisipasi subyek secara umum dalam menjawab pertanyaan adalah $59,71 \%$, dan keterlibatan atau peran aktif subyek pada setiap sesi pembelajaran adalah 44,38 \%. Perhatian $100 \%$ diberikan oleh subyek pada sesi pembelajaran bintang dalam apel, berikan popcornya, si jangkung dan si pendek. Partisipasi subyek dalam menjawab pertanyaan tertinggi adalah 64,28 \%, yaitu pada sesi pembelajaran kelihatan dan tidak kelihatan, nilai sebuah jiwa, dibalik kemarahan, tanganku untuk, strategi menyelesaikan konflik. Partisipasi subyek untuk terlibat langsung sebesar $71,43 \%$, yang terjadi pada sesi pembelajaran tentang lima kata penjaga hubungan.

\section{KESIMPULAN DAN SARAN \\ Kesimpulan}

Terdapat perbedaan nyata hasil pengukuran keterampilan sosial antara kelompok kontrol dan kelompok eksperimen, hal ini menunjukkan bahwa dalam penelitian ini pembelajaran nilainilai toleransi berpengaruh dalam meningkatkan keterampilan sosial siswa. Secara umum terjadi peningkatan skor keterampilan sosial pada kelompok eksperimen sebelum perlakuan dan sesudah perlakuan, baik secara individu pada masing-masing subyek, maupun peningkatan skor rata-rata.

Terdapat empat subyek $(28,57 \%)$ yang mengalami kenaikan kalsifikasi keterampilan sosialnya, yaitu sebelum perlakuan memiliki keterampilan sosial klasifikasi sedang menjadi berketerampilan sosial tinggi setelah perlakuan. Empat subyek $(28,57 \%)$ tidak mengalami perubahan klasifikasi keterampilan sosialnya, artinya sebelum perlakuan memiliki keterampilan 
sosial klasifikasi sedang, dan sesudah perlakuan klasifikasinya tetap sedang. Sementara enam subyek $42,86 \%$ ) memiliki keterampilan sosial tinggi sebelum dan sesudah perlakuan, namun secara skor pada kedua kelompok ini terjadi peningkatan antara skor sebelum dan sesudah perlakuan.

Hasil observasi menunjukkan sikap subyek selama berlangsungnya proses pembelajaran toleransi adalah : Secara rata-rata 88,57 \% subyek memberikan perhatian terhadap berlangsungnya pembelajaran, partisipasi subyek secara umum dalam menjawab pertanyaan adalah $59,71 \%$, dan keterlibatan atau peran aktif subyek pada setiap sesi pembelajaran adalah 44,38 \%. Perhatian $100 \%$ diberikan oleh subyek pada sesi pembelajaran bintang dalam apel, berikan popcornnya, si jangkung dan si pendek. Partisipasi subyek dalam menjawab pertanyaan tertinggi adalah 64,28 \%, yaitu pada sesi pembelajaran "kelihatan dan tidak kelihatan, nilai sebuah jiwa, dibalik kemarahan, tanganku untuk, strategi menyelesaikan konflik". Partisipasi subyek untuk terlibat langsung sebesar $71,43 \%$, pada sesi pembelajaran tentang" lima kata penjaga hubungan".

\section{Saran}

Untuk siswa: siswa yang terlibat dalam pembelajaran nilai-nilai toleransi diharapkan dapat mengembangkan dalam perilakunya seharihari. Dalam hubungannya dengan peningkatan prestasi sekolah, maka materi bintang dalam apel dan berikan pop-corn bisa menjadi pedoman, bahwa setiap orang mempunyai peluang yang sama untuk menjadi pandai dan berhasil. Sedangkan dalam menjalin persahabatan, maka materi pembelajaran, penghargaan, nilai sebuah jiwa dan lima kata penjaga hubungan bisa menjadi dasar atau pedoman dalam pergaulan.

Untuk sekolah: keterampilan sosial memegang peranan yang penting dalam proses pendidikan terutama dalam proses perkembangan kepribadian siswa, sehingga pembelajaran dan pengembangan keterampilan sosial harus terus menerus diupayakan untuk tujuan tersebut, modul pembelajaran nilai-nilai toleransi yang dipakai dalam penelitian ini perlu secara intensif dan berkesinambungan diajarkan kepada para siswa. Melalui program yang lebih terstruktur serta alokasi waktu yang berkesinambungan.

Penelitian ini masih banyak keterbatasan dan kelemahan, oleh sebab itu perlu dilakukan penelitian lanjutan dengan menggunakan waktu yang lebih lama, agar pembelajaran nilai-nilai toleransi yang terkandung dalam modul ini bisa dicerna dan diaplikasikan secara maksimal oleh para siswa dalam kehidupan sehari-hari.

\section{DAFTAR PUSTAKA}

Asri, C. B. (2004). Pembelajaran Moral. Jakarta: Rineka Cipta.

Azwar, C. (2004). Metode Penelitian. Yogyakarta: Pustaka Pelajar.

Barus, G dan Sri, H. (2011). Kumpulan Modul Pengembangan Diri. Yogyakarta: Universitas Sanata Dharma.

Cartledge dan Midburn . (1995). Teaching Social Skills to Children and Youth: Innovative Approaches. Retrieved from f4jar.multiply.com: http.//f4jar.multiply.com/journal/item/191

Dibyorini, MC. Candra, R. (2005). Solidaritas Sosial dalam Kemajemukan. Journal Ilmu Sosial Alternatif, Volume VI Nomor 12.

Efianingrum, A. (2007). Kultur Sekolah Yang Kondusif Bagi Pengembangan . Dinamika Pendidikan.

Elmubarok, Z. (2008). Membumikan Pendidikan Nilai. Bandung: Alfabeta.

Gardner, H. (2003). Multiple Intelligence . Jakarta: Inter Aksara.

Ghufron, A. (2007). Pengembangan Pembelajaran Berbasis Kompetensi Bervisi. Journal Dinamika Pendidikan, No.1/Tahun XIV/ Mei.

Goleman, D. (1999). Emotional Intellegence. Jakarta: Gramedia Pustaka Utama.

Green, P. (2001). Teaching Kids Tolerance. Retrieved from http://www.wholefamily.com/: http://www.wholefamily.com/aboutyourkids/children_prejudice.html 
Gulen, F. (2011). Cinta dan Toleransi. Tangerang: Bukindo Erakarya Publising.

Hanafiah, A. (2009). Toleransi dalam Masyarakat Plural Memperkuat Ketahanan. Puslitbang Kementrian Sosial Republik Indonesia.

Handarini, D. (2000). Pengembangan Model Pelatihan Keterampilan Sosial. Malang: Universitas Negeri Malang.

Harefa, A. (2004). Menjadi Manusia Pembelajar. Jakarta: Penerbit Harian Kompas.

Hurlock, E. B. (2010). Psikologi Perkembangan Suatu Pendekayan . Jakarta: Erlangga.

Indreswari, H. Carolina, L.R. Triyono. Wasis, D.D. (2010). Model Pengukuran Ketrampilan Sosial Untuk SMP. Malang: Universitas Negeri Malang.

Mukhtar, Desvi. Y, dan Noor, R.H. (2006). Efektivitas Art Therapy Untuk Meningkatkan Ketrampilan Sosial Pada Anak Yang Mengalami Gangguan Perilaku. Psikologia vol.2.

Nuswantari. (2018). Model Pembelajaran Nilai-Nilai Toleransi untuk Anak Sekolah Dasar. Premiere Educandum: Jurnal Pendidikan Dasar dan Pembelajaran, Vol 8 No 1.

Patnani, M. (2005). Kegiatan Pengajaran Nilai Toleransi untuk Anak Usia 4-6 Tahun. Pascasarjana Fakultas Psikologi Universitas Indonesia.

Prawiradilaga, D. (2007). Prinsip Desain Pembelajaran . Jakarta: Kencana Prenada Media Group.

Prihartanti,N. Abdulah,A. Eny, P. (2007). Model Pembelajaran Nilai Toleransi Untuk Anak Usia Sekolah Dasar. Laporan Penelitian Hibah Bersaing DIKTI.

Purwanti, E. ( 2007). Pengaruh Pemberian Dongeng Cerita Pewayangan terhadap Penalaran Moral Anak. . Skripsi. Surakarta: Fakultas Psikologi Universatas Muhammadiyah Surakarta.

Salim, H. (2003). Belajar Bersama Pluralisme : Sekelumit Pengalaman. Wacana, 223.

Santrock, J. W. (2002). Life - Span Development. Perkembangan Masa Hidup . Jakarta : Erlangga.

Shapiro, L. (1998). Mengajarkan Emotional Intelligence Pada Anak. Jakarta: Gramedia Pustaka Utama.

Subkhan, I. (2007). Hiruk Pikuk Wacana Pluralisme di Yogya. Yogyakarta: Kanisius.

Suyata. (2008). Refleksi Pendidikan Nasional dan Mencerdaskan Kehidupan Bangsa. Journal Dinamika Pendidikan Nol/Th.XV/Mei.

Syamril, J. R dan Irwan N.K. (2008). Pengaruh Pelatihan Kecerdasan Emosi Terhadap Keterampilan Sosial Siswa Akselerasi. Jurnal Keberbakatan dan Kreativitas. Jakarta: Gifted Review.

Thalib, S. (2010). Psikologi Pendidikan Berbasis Analisis Empiris Aplikatif. Jakarta: Prenada Media Group.

Uno, H. B. (2006). Orientasi baru dalam Psikologi Pembelajaran. Jakarta : Bumi Aksara.

Vogt, P. W. (1997). Learning to Live With Diversity and Difference. Tolerance and Education. 